Marquette University

e-Publications@Marquette

8-1-2007

\title{
On Their Own Ground: Strategies of Resistance for Sunni Muslim Women
}

Theresa Tobin

Marquette University, theresa.tobin@marquette.edu

Accepted version. Hypatia, Vol. 22, No. 3 (August 2007): 152-174. DOI. (C) 2007 Wiley-Blackwell. Used with permission.

The definitive version is available at www3.interscience.wiley.com. 


\section{On Their Own Ground: Strategies of Resistance for Sunni Muslim Women}

By Theresa Weynand Tobin

Drawing from work in feminist moral philosophy, Tobin argues that the most common methodology used in practical ethics is a questionable methodology for addressing practical problems across diverse cultural contexts because the kind of impartiality it requires is neither feasible nor desirable. She then defends an alternative methodology for practical ethics in a global context and uses her proposed methodology to evaluate a problem that confronts many Sunni Muslim women around the world.

Moral reasoning across diverse social, cultural, and religious contexts is one of the most complex challenges facing theorists and activists today. Consider, for example, Islamic prohibitions that deny Muslim women access to the public realm. In many Sunni Muslim communities, the prevailing view of women in the public sphere, particularly in politics and law, is that they do not belong there. In these communities, women's voices have "been branded awrah [taboo] and hence prohibited from public discourse (the discourse arena predominated by men)" (Wadud 2000, 18). Women in these communities cannot participate in any kind of political decision making or render legal opinions in Islamic jurisprudence. They are instead bound to the "private" realm of the family (Mernissi 1991, 49).

Western liberal moral theorists and human rights activists have joined the many Muslim women who are fighting against these prohibitions. But significant disagreements exist among these groups about how to support their opposition to Islamic exclusion of women. On one hand, liberal moral theorists and human rights activists generally contend that moral claims cannot be rationally verified only by religious and cultural standards. They maintain that in order to test the moral authority of a practice over and above its religious authority, it is necessary to adopt a standard of justification independent of a religious, or any other, context. On the other hand, many Muslim women feel it is necessary to fight these prohibitions with Islamic discourse and appeals to religiously based modes of reasoning and standards of evaluation.

These Muslim women call for moral reflection and criticism that originates from within their unique cultural and religious location. The methodology they are driving at shares common ground with Western feminist work on moral reasoning. Alison Jaggar argues that while work in feminist moral philosophy is quite diverse, a consistency of approach can be discerned (2000a, 457). instead of assuming ideals of rationality that ask us to be purely neutral or impartial in our

\section{Tobin 1}


moral thinking, many feminist moral philosophers contend that moral reasoning is inevitably partial, that the moral point of view is not single and transcendent but multiple and rooted in the social world (Jaggar 2000b). Yet, as Jaggar notes, feminists have a special stake in not abandoning the project of moral justification, for they "need some means of establishing that their critiques of those actions, practices, and institutions that rationalize or maintain male dominance are not merely personal opinion but are objectively justified" (2000b, 225). Accordingly, feminist philosophers have been forerunners in exploring the possibilities for constructing a philosophical framework that can address the inevitable partiality of moral inquiry.

In this essay, I synthesize recent feminist work on moral justification into a concrete methodology for evaluating practical moral problems affecting women in diverse social and cultural contexts. I begin with a brief account of moral liberalism and feminist criticisms of this approach. I then integrate recent feminist work on moral reasoning into a methodology for cross-cultural moral evaluation that I call "contextual transparency." Finally, I demonstrate how contextual transparency works in the case of Islamic prohibitions against women in public space.

\section{Moral Liberalism}

Moral liberalism does not refer to any particular normative moral theory but instead describes a general moral methodology that many standard nonfeminist moral theorists share, including social contract theorists, human rights theorists, utilitarians, and Kantians. The various moral theories that fall under the heading "moral liberalism" differ with respect to the particular methods of moral justification they propose. However, they share certain methodological assumptions about what criteria any legitimate method of moral justification must satisfy. ${ }^{1}$ According to the moral liberal, influences that arise from socially, culturally, or religiously based beliefs, personal relationships, psychological idiosyncrasies, or other contingent features of one's social identity tend to bias one's ordinary moral thinking and cloud sound moral judgment. I refer to these collectively as contextual values since they are value-laden influences on moral thinking that vary over time and across social and cultural context.

For the moral liberal, while contextual values may contribute to the formation of people's moral beliefs and the practices they support, moral claims cannot be objectively verified by anything that is tied to a particular way of life. For example, my culture or religion may tell me that abortion is a grave moral wrong. According to the moral liberal, however, in order to know whether this claim carries moral weight - that is, in order to know whether abortion is really morally wrong over and above whether my culture approves-I must check the claim from an

\section{Tobin 2}


independent perspective, a viewpoint that is not itself shaped by the contextual values of my own, or any, particular way of life. Only when tested from this perspective can we trust that claims have moral authority and not just the authority of culture or religion.

The most common strategy among moral liberals for achieving an independent perspective from which to evaluate the moral status of a practice is to become firmly grounded in normative moral theory. The moral theorist's job is to articulate a single, acultural, universally applicable procedure or set of principles that serve as independent standards of moral justification. Part of what makes a proposed standard valid is that it does not itself incorporate or reflect the contextual values of any particular way of life. So, moral liberals strive to formulate a procedure or set of principles for moral justification that is grounded in culturally invariant conditions such as the logical analysis of moral language (Hare 1981), a set of fundamental self-evident intuitions (Singer 1974, 1972), certain common features of our humanity (O'Neill 1996), or the necessary conditions for discursive practice (Habermas 1990). ${ }^{2}$ Once we are firmly grounded in the preferred normative moral theory and the standards of moral justification that moral liberalism provides, we can apply these standards to assess the practical problems with which we are concerned, wherever they may be occurring.

Moral liberals are not inattentive to social and cultural difference. They do assign a justificatory role to contextual values, but only the limited role of influencing the application of the procedure or principles with which we begin. For example, the preference utilitarian contends that a practice is morally warranted if it maximizes or promotes the equally weighted preferences of all individuals who are likely to be affected by that practice. Contextual values play a role in the application of this principle insofar as they influence what people's preferences in fact are. But the contextual values of any particular way of life are not supposed to shape the utilitarian method itself (Hare 1999, 12). Kantians tend to understand moral justification in terms of reasonableness: a practice is morally justified if reasons given to support that practice are reasonable to those in the relevant scope, which usually means those who are most affected by the practice. Recognizing the influence contextual values have on what people can accept as reasonable, Kantians often designate an explicit role for contextual values in their respective accounts of reasonableness by, for example, requiring that reasons be intelligible to those in the relevant scope. Yet, what ultimately determines whether a reason is warranted is whether that reason passes some version of the Kantian universalizability test, that is, whether all those in the relevant scope can adopt it without incoherence (O'Neill 1996, 54-59). In short, moral liberalism is a top-down methodology whereby the core justificatory mechanism is a procedure or set of principles that derives from certain theoretical commitments and that specifies the

\section{Tobin 3}


proper way to reason about moral matters; contextual values play only a subsidiary role in the application of the theory.

Feminist moral philosophers have been critical of such standard nonfeminist moral theories on a number of different grounds. Here, I highlight the strand of criticism Margaret Urban Walker has developed, namely, that the methodology of moral liberalism rests on a false view about the nature of moral knowledge. ${ }^{3}$ The assumption that it is possible to establish a single, acultural procedure or set of principles for moral justification depends on the assumption that there is an autonomous domain of the moral, a sphere of moral knowledge that is entirely separate from or independent of social, cultural, or religious understandings. according to Walker, "Western analytic approaches to ethics tend to assume that moral knowledge consists in a pure core, compact set of concepts, rules, or principles that can be detached from the particularities of any actual way of life and thus be made compatible with many, and that differences across cultures simply represent different applications of this same core" (1998, 89). I call this the autonomy of morality assumption.

Walker argues, however, that moral knowledge is not autonomous or, as she puts it, "conceptually modular" in this way. We cannot detach what we know and what we can know about morality from whatever other beliefs, both moral and nonmoral, we have about the world, in particular beliefs that constitute the social life of the respective ways of life we inhabit. Moral understandings are not only intimately bound up with other social and cultural understandings but they are also effected through them. This means that other social and cultural understandings frame or give shape to the meanings of moral concepts and principles. accordingly, in "differentiated moral-social worlds . . . 'we' may participate in different practices that support different moral concepts or may participate in practices whose differences give the same moral terms different meanings" (Walker 1998, 17). I refer to Walker's view as the "nonmodularity thesis of moral knowledge."

In order to bolster support for the nonmodularity thesis, Walker considers the example of the Golden Rule. it may seem that the Golden Rule- "do unto others as you would have them do unto you"-is a general moral principle that has an obvious egalitarian content. But this will not necessarily be the case. In a context "that does not already provide some patterns of universal egalitarian thinking[,] it may well only make sense in such ways as 'do unto others what is appropriate to their station as you would have done to you what is appropriate to yours"' $(2002,178)$. Those of us in communities that already have "patterns of universal egalitarian thinking" take for granted the typical egalitarian interpretation of the Golden Rule as obvious if not self-evident. Yet for such an interpretation to seem so obvious requires that our web of belief

\section{Tobin 4}


be such that the typical egalitarian interpretation seems the right one.

The nonmodularity thesis denies the autonomy of morality and with it the possibility of establishing a single, acultural procedure or set of principles for moral reasoning that is both substantive enough to do the work of moral justification and yet thin enough so as not to incorporate certain contextual values of any particular way of life. According to the nonmodularity thesis, there is no single, indisputable interpretation of any moral principle or procedure, and there is no independent or autonomous perspective from which to arbitrate among competing interpretations. Rather, contextual values will inevitably shape how one understands a moral rule or principle as well as which principles of reasoning or justification one finds valid.

Feminist moral philosophers are not alone in endorsing the nonmodularity of moral knowledge. Many nonfeminist communitarians, moral particularists, and antitheorists also accept some version of the thesis (Macintyre 1981; Taylor 1989; Walzer 1994; Williams 1985). Yet feminist work is distinctive in that it always attends to issues of power and authority. Feminist moral philosophers not only emphasize that moral inquiry is always partial and perspectival. They also demonstrate how standard accounts of moral justification (which are often presented as free from the influence of contextual values) tend to idealize modes of moral reasoning that attach to dominant social positions and then treat other ways of reasoning about moral matters as not only different but also deviant or irrational. ${ }^{4}$ Feminists reveal how moral theory can reinforce harmful power relationships by privileging the agency and reasoning of those in positions of power at the expense of those who are socially marginalized.

I focus on this feminist-inspired endorsement of the nonmodularity thesis because I believe it best captures Muslim women's resistance to what many perceive as outsider or foreign analyses of the practical moral problems they face. For example, Muslim scholar-activist Maysam al-Faruqi is highly critical of one version of moral liberalism, human rights, because this approach does not provide an independent, unbiased standard of moral evaluation, but rather privileges secular identities and ways of reasoning about moral matters. I believe we can best understand her criticisms through a feminist-inspired endorsement of the nonmodularity thesis. In the next section, I briefly describe how one might evaluate Islamic prohibitions against women's presence in public space using a human rights approach, al-Faruqi's criticism of this strategy, and how her criticisms are best understood in terms of the nonmodularity of moral knowledge.

\section{Tobin 5}




\section{Assessing Islamic Prohibitions against Women's Presence in Public Space, Using a Version of Moral Liberalism}

Western feminist scholars often construe the various oppressive situations that Muslim women around the world confront as human rights violations. A human rights approach is a version of moral liberalism that presupposes the autonomy of morality. A particular set of human rights function as the autonomous standards against which the moral authority of practices and institutions can be determined. Human rights standards are supposed to be substantive enough to identify moral violations wherever they may be occurring but thin enough so as not to unfairly incorporate contextual values that attach to any particular community. They are supposed to capture that pure core of moral knowledge that is detachable from any particular way of life and thus made compatible with many.

An advocate of a human rights approach might argue that preventing women from access to the realm of politics and law violates their right to freely and equally participate in the governments of their respective countries, as expressed in article 21 of the Universal

declaration of human Rights. ${ }^{5}$ From this perspective, we see clearly that these prohibitions constitute a serious infringement on the inherent dignity and equal rights that these women enjoy qua human. In this particular case, the infringement may then be attributed either to an inherently patriarchal religion oppressing its female members or to the distorting influence of cultural patriarchy on otherwise benign religiously based doctrines.

Al-Faruqi criticizes a human rights approach because it fails to characterize adequately the oppressive situations that many Muslim women confront. ${ }^{6}$ She asks:

What becomes then of the self-identity of the Muslim woman, reduced here to a universal concept of womanhood, battered by a universal concept of manhood along universal lines of cultural patriarchal oppression that can be identified by a "universal" list of human rights and be fought by universal measures that can, at best, be tailored to their local culture as a dismissive gesture for those incapable of casting away their sentimental attachment to their religion? These approaches are unsatisfactory to the Muslim because they fail to identify her real problem, and they therefore fail to provide adequate solutions. $(2000,74)$

According to al-Faruqi, a human rights approach fails to capture the nature of the violations that many Muslim women face because many Muslim women do not identify themselves primarily as women, or even as human, but as Muslims. Though many Muslim women are well aware of certain oppressive situations they confront, they seek resolutions to these problems "as Muslims concerned whether the faith of Islam is indeed practiced the way it defines itself" (79). Since a human rights approach emphasizes the rights of all members of the human family (qua human),

\section{Tobin 6}


from the perspective of many Muslim women, this approach fails to identify the particular violations they suffer in terms that are meaningful to them and that accurately capture the nature of these violations as these women experience them.

According to al-Faruqi, the crux of the problem is that whatever standard of moral evaluation we use will function as a lens through which we define and reason about the moral violation that is occurring and propose solutions to that violation (72). A human rights lens characterizes Islamic prohibitions against women's presence in the public realm as an assault on their individual dignity as human and then recommends we fight these transgressions by implementing human rights standards in their local communities. These standards may be tailored to local cultural or religious understandings, at least to some extent, which is to say that cultural and religious context may influence the application of the standards with which we begin. However, the standards of evaluation themselves are not supposed to be tied to a Muslim way of life but rather to our common humanity.

From the perspective of those most directly affected by the practice under scrutiny a human rights analysis fails to identify their real problem precisely because it employs standards of evaluation that have nothing to do with Islam. Many Muslim women understand the particular forms of oppression they experience as an assault on their personhood as Muslim and as a perversion of the good life that revelation proclaims, and they seek resolutions to these problems in terms of their faith. What al-Faruqi and other Muslim scholar-activists are calling for is not an uncritical acceptance of or reliance on religion, but rather a way of engaging in moral reflection while remaining in their own skin and relying on sources of moral knowledge and processes of moral knowledge production that are tied to the particular moral-social worlds they inhabit. I believe the best way to understand al-Faruqi's criticism is in terms of a feministinspired endorsement of the nonmodularity of moral knowledge. According to al-Faruqi and other Muslim scholar-activists, religion is essential to an adequate understanding of the moral violations that many Muslim women face. Al-Faruqi's core criticism of human rights, and by extension of moral liberalism in general, is that it fails to appreciate that we cannot know what has gone wrong for many Muslim women morally speaking without knowing what has gone wrong for these women religiously speaking. This is precisely to affirm the nonmodularity of moral knowledge.

The nonmodularity thesis contends that we can know the nature of a moral violation only through and in terms of the other social, cultural, and religious understandings that shape the moral-social worlds of those most directly involved. in this particular case, we can know the nature of the moral violations that many Muslim women face when they are banned from

\section{Tobin 7}


participating in politics and law only through and in terms of other cultural and religious understandings that shape the particular moral-social worlds these women inhabit. Al-Faruqi is not arguing that we need to be more sensitive to actual shared understandings in order to be more persuasive in our arguments against these oppressive practices or in order to be more respectful of those we aim to help. This may well be true; however, her point is that if we fail to define and evaluate the violations that Muslim women experience in terms of Islamic discourse, then we fail to accurately describe the moral nature of these violations as these women experience them. ${ }^{7}$ Her point is that the domain of the moral is not autonomous and that moral evaluation of the oppressive situations that many Muslim women confront needs to start not with theoretical commitments but with the particular shared understandings of those most directly involved, with their own religiously based ways of reasoning about the problems they face.

Furthermore, I believe al-Faruqi's criticisms motivate a feminist-inspired endorsement of the nonmodularity thesis. That is, a concern with the ways in which inattention to the inevitable influence of contextual values on theoretical work can reinforce harmful power relationships by generating accounts of moral justification that idealize the reasoning of those who inhabit dominant social positions and then treat other ways of reasoning as deviant or irrational. Many Muslim women are already marginalized in their local communities by being denied access to the realm of politics and law, their voices being branded taboo. There is a danger that these women will be doubly marginalized by theoretical work in ethics (especially work that influences international discussions about Muslim women) that treats religion as an inevitable source of bias on sound moral thinking and casts religiously based moral reflections and analyses as deviant or irrational.

The nonmodularity of moral knowledge denies the possibility of an autonomous perspective from which to assess the moral authority of any particular practice; it entails that moral inquiry is always partial and perspectival, that contextual values are always present shaping what people take to be valid principles of moral justification, as well as how people interpret those principles. Yet taking the nonmodularity thesis seriously raises a new set of challenges. If it is impossible to identify an autonomous standard or method of moral justification, then how do we know which views have moral authority and which do not? If moral justification always takes place within actual shared understandings that shape a particular moral-social world then to what do we appeal in order to arbitrate between competing views within that world?

Recent work in feminist moral philosophy has begun to construct the resources necessary to meet these challenges by developing certain methodological tools that allow

\section{Tobin 8}


theorists to start with actual shared understandings without abandoning the project of moral justification. One such tool is transparency testing. The notion of transparency has been developed by several contemporary feminist moral philosophers including, Annette Baier, Sabina Lovibond, and, most recently, Walker. My aim in the next section of this essay is to synthesize this feminist work into a concrete moral methodology that theorists and activists can use to evaluate practical moral problems within diverse social and cultural contexts. I call this alternative methodology "contextual transparency" as this name captures its two most central features.

\section{Contextual Transparency}

In an article entitled "Theory and Reflective Practice," Baier suggests that a methodological approach to ethics should start on the ground. She recommends that we

try to reflect on the actual phenomenon of morality, to see what it is, how it is transmitted, what difference it makes. We may, as a result of the resulting consciousness of what morality is, think we can make some improvements in it; however, these will come not from surveying abstract possibilities, but from seeing how, given the way it is, it can, by some move we can now make, improve itself, work better, correct its faults. ... Philosophers need to work with anthropologists, sociologists, sociobiologists, psychologists to find out what an actual morality is; we need to read history to find out how it has changed itself, to read novels to see how it might change again. $(1988,46)$

I quote Baier at length here because her remarks begin to capture the essence of the alternative moral methodology that I am calling contextual transparency. Contextual transparency starts from the assumption that moral knowledge is nonmodular, that morality starts out thick and that theorists ought to start "in the thick of things," from where actual moral agents are, with the actual moral-social-cultural-religious understandings they have, with their own construals of the problems they face. Thus, in contrast to moral liberalism, contextual transparency contends that moral claims can be objectively verified by standards that are tied to a particular way of life. Contextual transparency does not aspire to establish a single, acultural universally applicable method of moral justification; rather, it aims to develop strategies for testing the moral authority of practices from within particular moral-social worlds using standards of evaluation and modes of reasoning that are tied to those worlds and their inhabits.

Contextual transparency takes as its starting point a set of assumptions about actual moral communities and actual moral agents. First, communities are bound together by some set of shared understandings, some minimal set of shared beliefs and values in virtue of which we recognize a moral "we." Second, in order to maintain and reproduce itself a community requires

\section{Tobin 9}


a certain degree of trust. Any remotely stable, functioning community requires relationships of trust among those living within it, as well as trust among them that certain basic understandings are common and that these understandings shape shared life (Walker 2002, 180).

Shared understandings include commonly recognized norms, principles, values, and commitments; understandings about to whom norms apply and under what conditions; understandings about who is responsible for what and to whom; common recognition about what are the appropriate sources of moral knowledge and reliable processes of moral knowledge production (Walker 1998, 202). To say that understandings are genuinely shared is to say that all who are supposed to live by them can trust that they really do express the way all of us ought to live, morally speaking. The advocate of contextual transparency understands the project of moral justification to be a matter of scrutinizing actual shared understandings in order to see if they are or can be genuinely shared by all who are supposed to share them, and she does this by determining whether or not conditions for trust in those understandings are met.

Conditions for trust in a particular set of understandings are met to the extent that those understandings are not held in place by any form of deception, coercion, manipulation, or epistemic rigging. A set of understandings and the practices they support cannot be genuinely shared if deceit and manipulation are required to hold them in place. We measure the extent to which a particular set of understandings and the practices they support are genuinely shared by using a critical methodological tool called transparency testing. Transparency testing exposes moral understandings that are not genuinely shared by seeing what is really holding them in place. If some form of deception, manipulation, or other abuse of power are holding them in place, then they do not have moral authority, and are not warranted from a moral point of view; the conditions for trust are not met. as Walker states: "if our way of life in reality betrays our shared understandings or if these understandings turn out to be driven by deception, manipulation, coercion, or violence directed at some of us by others, where all are nonetheless supposed to 'share' in this purported vision of the good, then our trust may not be sustained," and we may judge that the way we do live is not the way we ought to live $(2002,180)$.

Transparency testing certainly uses the force of consistency "among beliefs, among actions, and between beliefs and actions"; for example, are there inconsistencies between what we claim and what we do (Walker 1998, 220)? Yet it goes beyond testing for mere consistency to test whether and to what extent particular understandings require coercion, manipulation, or some other abuse of power in order to endure as "our" shared understandings. Transparency testing does not simply measure actual levels of consensus or mere agreement among the inhabitants of a moral-social world. In any particular community there may in fact be widespread

\section{Tobin 10}


support for a practice that upon close inspection fails the transparency test, a practice that may have been long held in place through the deceptive tactics of those in positions of power. Rather, transparency testing resembles a kind of wide reflective equilibrium whereby agents stand on what they think they know best about how things are supposed to be and use that information to test how things really are, turning up inconsistencies or deceptions along the way. It involves looking to see whether particular understandings that we are all supposed to share really are so or whether, instead, they are forced upon some of us by others, held in place by some abuse of power. On contextual transparency, moral justification occurs when people come to understand their way of life and are not embarrassed by it (Lovibond 1983, 158).

At this point, someone might object that a real distinction between contextual transparency and moral liberalism does not exist, especially as regards transparency testing. Isn't the transparency test, like the principle of utility or Kantian universalizability, simply another proposal for an independent standard of moral justification that can be applied within and tailored to diverse social and cultural contexts? Transparency is certainly not an empty or purely formal idea; it does rest upon the assumption that moral warrant is ultimately about trust in shared understandings and between those who are supposed to share them. Yet the transparency test does not function as a standard of moral justification that is independent of any particular context. There is no single, indisputable interpretation of transparency, nor is there a single set of necessary and sufficient conditions that we can identify outside of any particular moral-social world that a set of understandings must meet in order to pass the transparency test.

Conditions for transparency will themselves always depend on context and will vary across diverse social and cultural contexts. Unlike those theories that fall under moral liberalism, which strive to provide the procedure or set of principles for moral justification, contextual transparency allows that there may be many different, contextually specific principles of moral justification and modes of moral reasoning. Another way of putting it is that on moral liberalism differences across social and cultural contexts can only enter once we have established the correct procedure or set of principles for moral justification. On contextual transparency, difference enters in from the start as the shared understandings of those most directly involved determine which modes of moral reasoning and which standards of evaluation we will use.

Transparency testing is not a principle that we apply but something that we do, and any enactment of it will embody some particular moral perspective or tradition. For example, Walker notes that exercises of transparency by feminist ethicists working within the tradition of Western academic ethics are "of specifically democratic, participatory, and egalitarian kinds, squarely

\section{Tobin 11}


founded on moral and political ideals of modern Western social thought" $(1998,73)$. In contrast, Muslim women who strive to make transparent the unwarranted gender bias that sustains Islamic prohibitions against women's presence in the public realm are not likely to invoke the ideals of modern Western social thought, but instead to rely on Qur'anic notions of justice, dignity, and equality. Individuals make their particular set of understandings transparent by invoking particular ideals, standards, and ways of reasoning that attach to their unique moralsocial worlds. Transparency is not a free-floating, independent principle of moral justification but a contextually specific practice of uncovering nasty and abusive power arrangements.

I believe transparency testing captures what actual moral agents are already doing as they strive to make their communities and their lives within those communities better. Nonetheless, it is not something that only "insiders" can or should do. Sometimes "outsiders" may be in a better position to discover failures of transparency that, for a variety of reasons, may be invisible or difficult to see by those who have been living within a moral-social world for a long time. yet contextual transparency requires moral philosophers and other theorists and activists to make their work much more interdisciplinary than it may already be; it requires that we read history, anthropology, critical race and gender studies, theology, and so on, and that we immerse ourselves as far as possible into the moral-social worlds of those whose practices we scrutinize; ideally, it also requires that we engage in dialogue with and do a lot of listening to those most affected by the practices we scrutinize.

Contextual transparency has at least two advantages over moral liberalism. First, it is philosophically more defensible because it rests on a more accurate understanding of the nature of moral knowledge, that moral knowledge is nonmodular. it does not aspire to identify a single, acultural procedure or set of principles for moral justification but instead acknowledges that there may be many culturally specific ways of reasoning about moral matters equally capable of generating warranted moral judgments. Second, it is more practically desirable. Insofar as contextual transparency requires theorists to reason about practical moral problems in terms of the shared understandings of those most directly involved, it is more likely to respect the dignity and agency of those we aim to help and to be more effective in helping them. Admittedly, contextual transparency, and in particular transparency testing, becomes much more intelligible when we see it in use. In the next section of the paper I demonstrate how contextual transparency works in the case of Islamic prohibitions against women's presence in the public realm.

\section{Assessing Islamic Prohibitions against Women’s Presence in Public Space,}

\section{Tobin 12}




\section{Using Contextual Transparency}

In contrast to the moral liberal, the advocate of contextual transparency begins a moral evaluation of Islamic prohibitions against women's presence in the public realm on the ground from within the actual moral-social world in which these prohibitions occur, by first trying to understand as much as possible about the religious understandings that shape shared life among Sunni Muslims. The advocate of contextual transparency aims to understand Sunni beliefs about which sources of moral knowledge are most important and beliefs about which are the most reliable processes of moral knowledge production, with an eye toward how the particular set of understandings prohibiting women from access to politics and law were developed and how they have remained in place.

The most fundamental and important source of moral knowledge within the Sunni Muslim community is the Qur'an, as Muslims believe it to be the "unadulterated Word of God, which has become audible through Muhammad" (Schimmel 1992, 29). In addition to the Qur'an, the sunna of the Prophet Muhammad, which refers to the words and deeds of the Prophet that are relevant to the "way of Islam," is also considered a form of revealed knowledge. In the earliest Muslim community, if the Qur'an was not explicit about a particular action, the Prophet was consulted and his decisions and opinions were taken as expressive of divine will. accordingly, after the death of the Prophet, the need to preserve his sunna lead to the development of hadith, which is the second most important source of moral knowledge in the Sunni Muslim community. Taken together, the Qur'an and hadith form the Muslim scriptures.

Islamic justifications for the exclusion of women from the public sphere come in large part from judgments about the alleged intellectual and moral inferiority of women. This view of women derives in part from two primary Islamic sources: (1) traditional tafsir (exegesis) of the Qur'anic creation stories, which allege that the Qur'an specifies essential differences between men and women and the intellectual and moral superiority of men over women, and (2) a popular hadith in which the Prophet allegedly warns against allowing women purview over political and legal matters. Here, I discuss traditional interpretations of the Qur'anic creation stories and Amina Wadud's critical exegesis that reveals why these traditional interpretations are unwarranted. I then discuss briefly the most popular hadith used to justify this view of women, and Fatima Mernissi's assessment that this hadith is not legitimate and should be rejected as a reliable source of moral knowledge. Finally, I discuss other contextual factors that have influenced the development and perpetuation of moral understandings about the role and status of women as morally and intellectually weak, including cultural patriarchy, poverty, and Islamist movements. Exercises of transparency occur along the way, as these women expose

\section{Tobin 13}


understandings that are based on abuses of power, but I conclude this section by explaining explicitly how this practice of denying women access to and participation in the public realm constitutes a failure of transparency.

\section{The Qur'an}

Though Muslims view the Qur'an as the literal word of God, even God's literal words must be linguistically analyzed in order to establish what the divine will intends through the text. Accordingly, much of the moral knowledge that we get from the Qur'an comes from tafsir, which is the human development and interpretation of the Qur'an, the science of exegesis and commentary. There are elaborate procedures in place for engaging in Qur'anic exegesis, which include an extensive command of the linguistic and grammatical structures of Arabic. Muslims uphold a sharp distinction between the divine word and tafsir, as tafsir is not to be equated with the word of God (Wadud 2000, 11). Thus Muslim scholars do the best they can to interpret and understand the message(s) of the Qur'an, but always with the knowledge that no human articulation of the divine word enjoys absolute or ultimate authority as the only possible understanding of the text. Particular exegeses and commentaries are authoritative to the extent that they are the result of following best exegetical and interpretive practices and that they are consistent with the overall worldview of Qur'anic justice.

Traditional exegesis alleges that the Qur'an specifies the moral and intellectual weakness of women and their inferiority to men in this regard. Since holding positions of legal authority in the Sunni community is based on moral and intellectual criteria, defining women as morally and intellectually weak by nature serves to support the view that women are naturally unsuited to hold these positions. The central theological assumptions that underscore this view of women are that God's primary creation was man, that woman was created from man and is thus secondary and derivative, and that woman was not only created from man but also for man making her existence instrumental, not intrinsically valuable (hassan 2000, 235).

Wadud critiques established inegalitarian interpretations of the Qur'an in two ways. First, she engages in critical exegesis of the text in order to provide alternative interpretations of the Qur'anic creation story and the events in the garden, alternatives that she argues are more faithful to the text. Next, she demonstrates that these alternative interpretations should also be favored because they are more consistent with the Weltanschauung of the text, the overall picture of Qur'anic justice. in particular, she shows that men and women were created from a single nafs (source); although men and women were created as a pair and with biological distinctions, the Qur'anic creation story does not assign nor does it support the assignment of

\section{Tobin 14}


cultural or psychological differences that restrict men and women to specific functional roles within society $(1999,15)$.

According to Wadud, the most popular verse in the Qur'an describing the creation of human beings is: "and min his ayat (is this:) that he created you (humankind) min a single nafs, and created $\min$ (that nafs) its zawj, and from these two he spread (through the earth) countless men and women (4:1)" (quoted in Wadud 1999, 17). Wadud's exegesis begins with a general analysis of possible usages of the key terms: min, nafs, and zawj. Min has two primary meanings: it can be used either as the english preposition "from," to imply the extraction of one thing from another, or to mean "of the same nature as" (Wadud 1999, 18). Nafs has both a common and technical usage. The common usage of nafs refers to "self" and the technical usage of nafs refers to "the common origin of all humankind" (19). Grammatically nafs is feminine; however, conceptually it is neither masculine nor feminine but instead forms an essential part of all human beings. Zawj commonly refers to "mate" or "spouse." Grammatically zawj is masculine, though conceptually it is neither masculine nor feminine and is used in the Qur'an not only in reference to the creation of humankind but also in reference to the creation of animals and plants (20).

Traditional interpretations of the Qur'anic creation story, such as the one in alZamakhshari's commentary, translate the second use of min as "of the same nature" and the third use of min as "from." These traditional interpretations of the Qur'an then posit the first created human being as male and as made "complete, perfect, and superior," while the second created human being, the female, is taken to be derived from him and is thus not his equal because she is less than the completed, perfect, whole (Wadud 1999, 18-19). One reason that traditional commentators might have adopted this familiar interpretation is that there are other verses on the topic that use the word ja'al, which means "to create something from another" and thus gives the word min the meaning "from." yet Wadud points out that there are also verses on this topic that use the plural of nafs (anfus) and the plural of zawj (azwaj), which then get interpreted as "your mates are of the same type as you" (19). because the Qur'anic creation story is so sparse with details, commentators such as al-Zamakhshari bolster support for their gendered interpretation of the story by appealing to the biblical version of the creation story, a version that more explicitly posits that Eve was created "from" Adam (18).

Wadud argues, however, that there are no good reasons to make this gendered read of the creation story as it is stated in the Qur'an, primarily because the text does not explicitly state that creation began with either the male or the female. The text does not specify that the creation of human beings began with the male, or even that it began with the nafs of the male.

\section{Tobin 15}


We cannot assume that allah "planned to begin the creation of humankind with a male person" as the "Qur'anic version of the creation of humankind is not expressed in gender terms" (1999, 20).

Moreover, the use of zawj supports a gender-neutral interpretation of the creation of humankind. Wadud notes that zawj is used to denote one in a necessary or contingent pair and that it is used in the text to refer not only to the creation of humankind but also to the creation of plants and animals $(1999,20)$. This usage of zawj supports the understanding that everything in the created world, being made in pairs, is different and separate from Allah, who is one and simple. in "this usage, a pair is made of two co-existing forms of a single reality, with some distinctions in nature, characteristics, and functions, but two congruent parts formed to fit together as a whole" (21). The fact that everything in the created order is created in pairs means that the fullness of being of each member of a pair is contingent on the other member. The idea is that out of one and the same reality Allah formed two physical manifestations, male and female, which are distinct but inextricably linked to each other, and this is the case not just for human beings but for all of creation. Thus, Wadud concludes, "in this contingency, the creation of both the original parents is irrevocably and primordially linked; thus the two are equally essential" (21).

Once we understand the usage of nafs as referring to a single origin for humankind and the use of zawj as not identifying one particular part of the pair, namely the female part, but as indicating that out of a single nafs Allah created two physical manifestations of this same reality, the exegetical scaffolding holding the traditional interpretation of the Qur'anic creation stories in place begins to falter. The Qur'anic creation story is not told in gendered terms; rather, gender was read into the Qur'anic creation story as a product of tafsir. According to Wadud,

Femininity and Masculinity are not created characteristics imprinted into the very primordial nature of female and male persons, neither are they concepts the Qur'an discusses or alludes to. They are defined characteristics applied to female and male persons respectively on the basis of culturally determined factors of how each gender should function. They have figured very strongly in interpretation of the Qur'an without explicit substantiation of their implications. $(1999,22)$

Wadud concludes that given the meaning of the relevant terms an accurate translation of verse (4:1) is: "O Mankind! be careful of your duty to your Lord Who created you from a single nafs, and from it created its zawj, and from that pair spread abroad [over the earth] a multitude of men and women" (22). The Qur'anic creation story does not support the view that women are, from the moment of creation, made essentially different from men in either their moral or intellectual capacities. indeed, although the Qur'an acknowledges the differences in biological functioning of

\section{Tobin 16}


men and women (for example, women bear children and men do not), these differences refer only to the physical manifestation of the human form and do not support cultural or psychological infusions in the text that give women a nature that is essentially different from or inferior to men.

Wadud's critical exegesis is an exercise in transparency. invoking the community's own shared understandings about how reliable moral knowledge is generated Wadud makes transparent the embarrassing truth that interpretations of the Qur'anic creation stories, which posit women as intellectually and morally inferior to men, do not derive from best exegetical practices but are rigged by the influence of cultural patriarchy. Proper linguistic and grammatical analysis of the Arabic terms used in the Qur'anic creation stories generate interpretations of the Qur'an specifying that God created women and men equal in moral and intellectual capacity. Moreover, Wadud bolsters support for her exegetical work by pointing out that a more egalitarian interpretation of the creation story is more consistent with the overall worldview of Qur'anic justice than are the traditional interpretations. "Second only to the existence of God, no other religious or moral principles are more emphasized in the Qur'an . . . than the principles of uprightness, equality, and temperance" $(2000,15)$. The moral themes that one sees continuously repeated in the Qur'an are themes of guidance, individual and moral responsibility, and equality $(1999,25)$. at the moment of creation, "Allah defines certain traits universal to all humans and not specific to one particular gender, not to any particular people from any particular place or time" (26). What is important about the creation story is that all human beings are designed with fundamentally equal moral and intellectual capacities.

\section{Hadith}

The second most important source of moral knowledge for Sunni Muslims is hadith reports. Hadith are officially sanctioned reports specifying what the Prophet did or said on a particular occasion with respect to a particular issue, reports that contain his "exemplary words, deeds, and gestures" (denny 1994, 159). Each hadith has two main parts: an isnad or chain of transmitters whose original source is a Companion of the Prophet (someone close to the Prophet) and the matn, or main body of the report (Schimmel 1992, 52). The isnad comes at the beginning of any particular hadith and is a citation of all the people who played a role in the transmission of the hadith. The isnad is the most important part of the hadith, for the reliability and strength of a particular hadith depends entirely on the reliability of those individuals involved in the transmission of the report (Denny 1994, 161-62). Any given hadith gets its authenticity from the strength of its isnad such that what matters most in determining whether and how a

\section{Tobin 17}


particular hadith will function as a source of moral knowledge in the community is the character and intelligence of the transmitters.

There are numerous criteria for distinguishing among hadith in order to classify them into one of several categories (denny 1994, 162). Sound is the best rating and marks a universally accepted hadith and one that weighs most heavily as a source of moral knowledge; weak marks a hadith that weighs less heavily, if at all, as a source of moral knowledge; unconditionally rejected indicates a hadith that should not weigh at all as a source of moral knowledge. in order for a hadith to be considered sound, the original source and all of the subsequent transmitters must be considered sound (Denny 1994, 62). There are three primary criteria that the original source of a hadith must meet in order to be classified as sound: (1) a proximity requirement (that is, the person had to have been close enough to the Prophet), (2) a memory requirement to determine whether or not the person had a reputation for remembering "just anything," and (3) a moral/intellectual requirement that includes among other things a reputation for honesty and integrity not only in reporting the hadith but also in his or her daily life (Mernissi 1991, 49).

Even though there exists an excepted "canon" of hadith, and even though the hadith included in these collections are accepted as true, any individual believer "has the right to have all the pertinent information about the source of the hadith and the chain of transmitters, so that he or she can continually judge whether they are worthy of credence or not" (Mernissi 1991, 35). Thus, any believer has the right to investigate a hadith, and potentially to challenge the legitimacy of a hadith if she has convincing grounds for so doing.

The hadith most frequently used to exclude women from public life claims that the Prophet said: "those who entrust their affairs to a woman will never know prosperity" (Mernissi 1991, 49). This hadith appears in the Sunni canon of hadith, and as such it is considered sound (the highest ranking and most reliable). The original and sole source of this hadith is abu bakra, a Companion of the Prophet.

Exercising her right to engage in hadith criticism, a right that all believers have, Fatima Mernissi investigates the legitimacy of this hadith. Mernissi argues persuasively that the isnad of this hadith is not sound, which means that the hadith itself is not sound, by showing that Abu Bakra fails to meet all of the three necessary conditions for being a sound transmitter. While Abu Bakra does meet the first condition, the proximity requirement (if the Prophet made this statement about women he was close enough to the Prophet to have heard it), it is questionable whether or not he meets the memory requirement. Historical evidence suggests that Abu Bakras was in the habit of recalling hadith at politically opportune times, or when doing so was otherwise to his advantage. Thus, it seems likely that Abu Bakra had a habit of remembering

\section{Tobin 18}


“just anything" (Mernissi 1991, 58).

The most substantial blow, however, is that Abu Bakra does not meet the moral criteria necessary for being a sound transmitter. There is quite a bit of historical evidence indicating that Abu Bakra did not have a reputation for honesty and integrity in everyday life, and certainly not in life's more critical moments. One stark example is a case in which Abu Bakra was flogged for false testimony against a man who was accused of fornication, a crime that at the time was punishable by death; he lied in a rather serious affair that could have cost another his life, and this is the kind of behavior that diminishes one's ability to effectively meet the moral criteria required in order to be considered a sound transmitter (Mernissi 1991, 60-61).

Mernissi's critical examination of this hadith is an exercise in transparency exposing the misuse of hadith reports in an effort to deny women access to political participation. Exercising her right to engage in hadith criticism she demonstrates that this particular hadith is not a reliable source of moral knowledge and should not be trusted as such. Given the community's own shared understandings about the proper use of hadith, if we reject abu bakra as a sound source of hadith then we must reject the hadith that he is the original source of, especially if he is the sole source. His failure to meet all three necessary conditions for being a sound transmitter means that the hadith used to deny women access to public life, "those who entrust their affairs to a woman will never know prosperity," is at best weak, for its original and only source is at best a weak transmitter, and thus should be rejected as a reliable source of moral knowledge for the Sunni Muslim community.

\section{Other Contextual Considerations}

As Mernissi and Wadud point out, the moral understandings that posit women as morally and intellectually weak rest on misinterpretations and misuses of the two primary sources of moral knowledge for the Sunni community. Mernissi and Wadud contend that one major factor contributing to these manipulations of the Qur'an and hadith is cultural patriarchy. Yet, certain other contextual factors have also contributed to holding in place this view of women and the practices it supports including: the influence of the severe poverty that many Muslims and in particular Muslim women in Sunni communities around the world face, the historical experience of colonization, and Islamist movements that have developed to oppose the threat of Western political, economic, and cultural imperialism.

For example, Riffat Hassan notes that one major reason for the continued prevalence of views about the alleged intellectual and moral weakness of women, views that are not warranted by a correct reading of the Qur'an, is that "the masses of Muslim women are steeped

\section{Tobin 19}


in poverty and illiteracy" and "have been systematically denied the opportunity to acquire the critical tools whereby they can examine the roots of their tradition and . . refute the arguments that impose unjust laws and restrictions upon them in the name of Islam" (235). Economic hardship thus makes it almost impossible for many Muslim women to engage in the kind of hadith criticism Mernissi conducts or the exegetical work Wadud has completed; this, in turn, allows unwarranted views about women's role in society to go largely unchallenged. Furthermore, as Wadud notes,

Where Muslim identity is stronger over against externally set colonialist standards, there is greater flexibility toward women's development and greater public acknowledgement of women's valuable contributions inside and outside of the family. When Muslim identity is weak in the face of external pressures, women are more closely guarded not only from perceived and real external threats but also from internal flexibility and change. Changes in the role and status of women seem to occur more within the context of a stable group identity. $(2000,3)$

Thus the experience of colonization and the existence of contemporary Islamist movements that seek to preserve Muslim identity in the face of (perceived or real) Western imperial threat combine to perpetuate views about women that proper interpretation and use of the Qur'an and hadith would not support.

\section{A Failure of Transparency}

For Sunnis, a necessary condition for moral understandings to be genuinely shared is that they derive from accurate interpretations of the Qur'an and proper uses of hadith. Community members trust that when accessing sharia knowledge, which is the established body of God's law unto which all Muslims are bound, and producing the best human articulation of God's revealed message, jurists and scholars follow rules and procedures for tafsir and hadith science. Thus to say that moral understandings are genuinely shared in the Sunni community is to say that they have been formed through procedures and rules that the community has established and agreed on as best practices for accessing these understandings from revelation, and not merely to say that many community members agree with the results.

When we make transparent Islamic prohibitions that deny women access to and participation in public life we see that they are not genuinely shared but are held in place by deceptive and manipulative uses of the two most important sources of moral knowledge in the Sunni community. A number of factors have contributed to this manipulation and deception. Cultural patriarchy played an extremely significant role in initial misinterpretations of the Qur'an

\section{Tobin 20}


and misuses of hadith. Poverty and illiteracy have helped hold these moral understandings in place by preventing many Muslim women from exercising their rights to check that juristic opinion is properly formed. And in seeking to define and secure Muslim identity in the face of perceived and real Western imperial threats, Islamist movements have also strengthened and perpetuated these beliefs about women by asserting that such beliefs represent "true" Islam and by generating and enforcing social codes that restrict women's mobility. Thus transparency fails because once we "see through intervening media to what is really there" we see that prohibitions against women's presence in the public realm violate the community's own understandings about how reliable moral knowledge is produced and thus do not have the moral authority those in positions of power claim they have.

Ideally contextual transparency requires much more than the analysis I have given above, including a sophisticated exploration of primary source material, an examination of other important sources of moral knowledge within the Sunni community, and a closer study of the historical, political, and economic factors that have shaped Islamic discourse. My aim in this essay has been the more modest one of synthesizing recent feminist work on moral justification into a concrete moral methodology that takes seriously the nonmodularity of moral knowledge. I also hope to have shown how we can use this methodology to evaluate practical moral problems affecting primarily women in more traditional kinds of communities. I believe that moral liberalism remains a popular methodology in part because of the concern that we preserve a commitment to moral objectivity and in part because of the belief that moral objectivity and moral particularity are opposed. Feminist work in moral epistemology demonstrates that this belief is mistaken: moral justification always takes place between particular people drawing on particular modes of moral reasoning that are grounded in particular ways of life, but this need not threaten the objectivity of the process or the outcome.

\section{Notes}

I wish to thank Alison Jaggar and Audra King for their helpful comments on early drafts of portions of this essay, and Richard Tobin for proofreading and editing. I also wish to thank Peter Higgins for raising incisive objections to contextual transparency, which helped me clarify and strengthen the position and made this a much better essay. And finally, I thank the two anonymous Hypatia reviewers, who provided useful guidance for the revision process.

1. I refer to this methodology as "moral liberalism" because it is a methodology that liberal moral theorists share.

2. I do not mean to ignore or minimize the significant differences among these

\section{Tobin 21}


moral theories, especially in regard to the status their proponents claim for them. For example, whereas hare $(1981,1999)$ claims to derive a version of preference utilitarianism from the logic of moral language, Habermas (1990) argues that concrete historical conditions of modernity have made possible the discourse ethicist's procedural method of moral justification. What all moral liberals share, however, is the idea that we must establish a single method of moral justification that is not rooted in any particular way of life or conception of the good. Even for Habermas the conditions of modern life that give rise to discourse ethics become the common feature of humanity upon which a single, acultural method of moral justification can be based.

3. What I call "moral liberalism" is the methodology that Walker (1998) refers to as the "theoretical-juridical model."

4. Indeed, one might argue that this criticism gave rise to the field of feminist ethics with Gilligan's (1982) critique of Lawrence Kohlberg's stages of moral reasoning. Gilligan demonstrated that Kohlberg idealized typically male ways of reasoning about moral matters and then concluded that female subjects who display different ways of reasoning in fact exhibit inferior levels of moral development.

5. Article 21 states: "(1) Everyone has a right to take part in the government of his country, directly or through freely chosen representatives. (2) Everyone has the right of equal access to public service in his country. (3) The will of the people shall be the basis of the authority of government; this will shall be expressed in periodic and genuine elections which shall be by universal and equal suffrage and shall be held by secret vote or by equivalent free voting procedures." U.N. General Assembly, "Universal declaration of human Rights," 1948, http://www.un.org/Overview/rights.html (accessed March 29, 2007).

6. Al-Faruqi does not specifically address Islamic prohibitions against women's presence in the public realm. She discusses a more general human rights approach, which I apply to this particular example.

7. Al-Faruqi is careful not to generalize for all Muslim women. She notes that some secular Muslim women may not be at all concerned to understand oppressive practices in Muslim communities in terms of Islamic discourse. her point, however, is that many Muslim women around the world self-identify first and foremost as Muslims, and in order to help these women solve the oppressive situations they face we must first understand the nature of the moral violations they experience in terms of their own religious commitments and faith (2000, 75).

\section{References}

\section{Tobin 22}


Annette Baier. 1988. Theory and reflective practice. In Applied ethics and ethical theory, ed. David M. Rosenthal and Fadlou Shehadi. Salt Lake City: University of Utah Press. Denny, Frederick. 1994. An introduction to Islam. New York: Macmillan Publishing Company. Faruqi, Maysam al-. 2000. Self-identity in the Qur'an and Islamic law. In Windows of faith, ed. Webb.

Gilligan, Carol. 1982. In a different voice: Psychological theory and women's development. Cambridge: Harvard University Press.

Habermas, Jürgen. 1990. Discourse ethics: notes on a program of philosophical justification. In Moral consciousness and communicative action. Trans. Christina Lenhardt and Shierry Weber Nicholsen. Cambridge: MIT Press.

Hare, R. M. 1981. Moral thinking: Its levels, method, and point. Oxford: Clarendon Press.

- 1999. Objective prescriptions. In Objective prescriptions and other essays. Oxford: Clarendon.

Hassan, Riffat. 2000. Issues of a woman's right to contraception. In Windows of faith, ed. Webb. Jaggar, Alison M. 2000a. Ethics naturalized: Feminism's contribution to moral philosophy. Metaphilosophy 31 (5): 452-68

-2000b. Feminism in ethics: Moral justification. In The Cambridge companion to feminism in philosophy, ed. Miranda Fricker and Jennifer hornsby. Cambridge: Cambridge University Press.

Lovibond, Sabina. 1983. Realism and imagination in ethics. Minneapolis: University of Minnesota Press.

Macintyre, Alisdair. 1981. The virtues, the unity of human life, and the concept of a tradition. In After virtue. Notre Dame, Ind.: University of Notre Dame Press.

McCloud, Aminah Beverly. 2000. Legal issues facing African American and immigrant Muslim communities in the United States. In Windows of faith, ed. Webb.

Mernissi Fatima. 1991. Women and Islam: An historical and theological enquiry. Trans. Mary Jo Lakeland. Oxford: Basil Blackwell.

O'Neill, Onora. 1996. Towards justice and virtue. Cambridge: Cambridge University Press.

Schimmel, Annemarie. 1992. Islam: An introduction. Albany: SUNY Press.

Singer, Peter. 1972. Famine, affluence, and morality. Philosophy and Public Affairs 1 (1): 229 43.

- 1974. Sidgwick and reflective equilibrium. Monist 58: 490-517.

Taylor, Charles. 1989. Sources of the self. Cambridge: Harvard University Press.

Wadud, Amina.1999. Qur'an and woman: Rereading the sacred text from a woman's

\section{Tobin 23}


perspective. New York: Oxford University Press

- 2000. Alternative Qur'anic interpretation and the status of Muslim women. In Windows of faith, ed. Webb.

Walker, Margaret Urban. 1998. Moral understandings. New York: Routledge.

- 2002. Morality in practice: a response to Claudia Card and Lorraine Code. Hypatia 17 (1): 174-82.

Walzer, Michael. 1994. Thick and thin: Moral argument at home and abroad. Notre Dame, Ind.: University of Notre Dame Press.

Webb, Gisela, ed. 2000. Windows of faith: Muslim women scholar activists in North America. Syracuse, N.Y.: Syracuse University Press.

Williams, Bernard. 1985. Ethics and the limits of philosophy. Cambridge: Harvard University Press. 